\title{
Review
}

\section{Cardiac Surgery in Advanced Heart Failure}

\author{
Roger Hullin ${ }^{1, *}$, Philippe Meyer ${ }^{2}$, Patrick Yerly ${ }^{1}$ and Matthias Kirsch ${ }^{3}$ \\ 1 Cardiology, Cardiovascular Department, University Hospital and University of Lausanne, Rue du Bugnon 46, \\ 1011 Lausanne, Switzerland; patrick.yerly@chuv.ch \\ 2 Cardiology, Department of Medical Specialties, Geneva University Hospital, University of Geneva, Rue du \\ Gabrielle Perret-Gentil 4, 1205 Geneva, Switzerland; philippe.meyer@hcuge.ch \\ 3 Cardiac Surgery, Cardiovascular Department, University Hospital and University of Lausanne, Rue du \\ Bugnon 46, 1011 Lausanne, Switzerland; matthias.kirsch@chuv.ch \\ * Correspondence: roger.hullin@chuv.ch; Tel.: +41-21-314-0052
}

Citation: Hullin, R.; Meyer, P.;

Yerly, P.; Kirsch, M. Cardiac Surgery in Advanced Heart Failure. J. Clin. Med. 2022, 11, 773. https://doi.org/ $10.3390 /$ jcm 11030773

Academic Editor: Piergiorgio Tozzi

Received: 30 November 2021

Accepted: 27 January 2022

Published: 31 January 2022

Publisher's Note: MDPI stays neutral with regard to jurisdictional claims in published maps and institutional affiliations.

Copyright: (C) 2022 by the authors. Licensee MDPI, Basel, Switzerland. This article is an open access article distributed under the terms and conditions of the Creative Commons Attribution (CC BY) license (https:// creativecommons.org/licenses/by/ $4.0 /)$

\begin{abstract}
Mechanical circulatory support and heart transplantation are established surgical options for treatment of advanced heart failure. Since the prevalence of advanced heart failure is progressively increasing, there is a clear need to treat more patients with mechanical circulatory support and to increase the number of heart transplantations. This narrative review summarizes recent progress in surgical treatment options of advanced heart failure and proposes an algorithm for treatment of the advanced heart failure patient at $>65$ years of age.
\end{abstract}

Keywords: end-stage heart failure; cardiac surgery; outcome

\section{Introduction}

Survival with heart failure (HF) has significantly increased in the last decades with the broad implementation of guidelines-directed medical therapy [1]. Nonetheless, HF almost always progresses towards advanced-stage HF characterized by persistent symptoms despite optimal medical treatment. Community-based studies report that advanced HF affects between 1 to $10 \%$ of all HF patients [2], and this prevalence will further increase. The reason for this continued surge is the ageing of the population, which involves an exponential rise in the incidence of HF with increasing age [3]. Furthermore, modern HF treatment attenuates progression of $\mathrm{HF}$ disease and prolongs survival with heart failure, and this beneficial effect will add further to the burden of advanced HF in the upcoming years [4]. Together, this concomitance explains why patients with worsening HF but also patients with de novo HF are older [5-7], which mandates the development of an algorithm taking care of the old patient with advanced HF.

The prognosis of advanced-stage HF remains poor with a 1-year mortality ranging from $25 \%$ to $75 \%$ [5-7]. Often, short-term therapy with inotropes remains the mainstay to improve the clinical condition and to reverse worsening end-organ function despite the fact that this treatment does not improve cardiovascular outcomes and even may worsen the prognosis [8]. Inotropes have therefore no place for routine treatment of chronic refractory advanced HF symptoms while being necessary in the acute setting and acceptable in a palliative-care setting.

In contrast, temporary MCS treatment provides an option to bridge patients with refractory symptoms to long-term mechanical circulatory support (LT-MCS) or heart transplantation (HTx), which remain the two acknowledged options of surgical treatment of advanced HF. While HTx can still be considered as the gold-standard treatment of advanced $\mathrm{HF}$, organ-donor shortages limit the broad application of this treatment option. Whether application of less-stringent criteria for donor selection can increase and expand the donor pool without repercussion on posttransplant survival remains to be followed. On the other hand, LT-MCS therapy has seen a significant surge of activity in the last years, in particular since smaller blood pumps became available [9]. Since then, not only the number 
of LT-MCS implantation has largely increased but also the clinical experience with this form of surgical treatment of advanced heart failure has expanded significantly. This resulted in an enlargement of the target population of LT-MCS, which nowadays also includes patients with pediatric or older age, congenital heart defects, and more advanced comorbidity.

This review intends to discuss the current evidence for temporary as well as durable MCS treatment and options to expand the donor heart pool for transplantation, and finally, it proposes an algorithm of how to care for the older-age patient presenting with advanced $\mathrm{HF}$.

\section{Definition of Advanced Heart Failure}

Acknowledging that evidence guiding therapeutic decision making in patients with advanced HF remains scarce [4], the European Heart Failure Association of the European Society of Cardiology more recently published a modern definition. This definition revisits existing criteria characterizing this patient group on the one hand while integrating novel elements into the definition on the other hand. Central criteria of this new definition remain the persistent severe symptoms of HF and a reduced maximal exercise capacity. The new definition now acknowledges in addition HF with mildly reduced LVEF and preserved LVEF as an additional cause of advanced HF besides non-operable severe valvular or congenital abnormality, isolated right-ventricular failure, or severe left-ventricular systolic dysfunction. Furthermore, malignant arrythmia is now considered as a clinical event in addition to intermittent episodes of pulmonary or systemic congestion or episodes of low-output requiring an unplanned visit or hospitalization within the last 12 months [8].

\section{Temporary Mechanical Circulatory Support}

The case against broad application of traditional inotropes is their potential to increase myocardial ischemia and to provoke tachyarrhythmia, while inotropes improve central and peripheral hemodynamics, reduce congestion, and alleviate end-organ dysfunction on the other hand $[10,11]$. Temporary MCS treatment, however, is shown to successfully bridge advanced HF patients to urgent HTx with compelling posttransplant results [12] and, therefore, represents a pertinent treatment option in situations of severe hemodynamic compromise.

Temporary MCS can be provided as bridge to recovery (BTR) or bridge to the decision (BTD) if it is not clear whether the clinical situation may offer future eligibility for durable treatment such as long-term MCS (LT-MCS) or HTx. If the patient is not eligible for either option because of ongoing severe infection, uncontrolled bleeding, or larger dekubitus ulcer, temporary MCS treatment can be maintained until the patient is recovering from temporary contraindication (bridge to candidacy = BTC). However, if the patient is eligible for HTx, temporary MCS treatment can be maintained as a bridge to urgent HTx (bridge to transplant = BTT) $[12,13]$. Additionally, if the patient is eligible for long-term mechanical circulatory support (LT-MCS) such as destination therapy (DT), temporary MCS may be maintained until clinical improvement provides acceptable peri-operative risk for LT-MCS implantation [14]. Often, these cases are difficult to manage; therefore, discussion of the patient with an advanced heart failure center is recommended to select the most appropriate short-term management strategy [8].

More recent studies provide helpful evidence for decision-making in advanced HF affording temporary MCS treatment and will be therefore discussed in the following.

\subsection{New Evidence for the Intra-Aortic Balloon Pump}

The intra-aortic balloon pump (IABP) is a catheter-mounted balloon sitting in the descending aorta. It augments the pulsatile blood flow by inflation during diastole, thereby displacing blood volume to the distal aorta. Simultaneously, inflation displaces blood to the proximal aorta, increasing thereby the mean pressure in the ascending aorta and the coronary arteries. On the other hand, deflation during systole reduces the afterload [15]. Intuitively, these characteristics should be beneficial to patients with left-ventricular (LV) 
ischemia and dysfunction; however, large, randomized trials evaluating IABP treatment failed to show improvement in cardiovascular-outcome parameters whether in the setting of acute myocardial infarction with or without cardiogenic shock or in the context of elective high-risk percutaneous coronary intervention [16-19]. Nonetheless, IABP is still broadly applied in this clinical setting [20].

However, IABP treatment has been applied in recent times more frequently for treatment of advanced HF, especially among patients awaiting HTx. Initially, this application was likely a response to the 2018 United Network for Organ Sharing (UNOS) policy change, which prioritizes patients to status 2 when bridged to heart transplantation with IABP [21]. Surprisingly, waitlist outcomes of these HTx candidates were improved as shown in a recent analysis, and, furthermore, posttransplant survival was not worse in patients with IABP treatment pretransplant [21]. However, prolonged IABP therapy debilitates the physical condition when applied using a transfemoral approach. Therefore, a more recent study tested the feasibility of percutaneous IABP placement via the axillary artery in order to promote ambulation and, thus, mitigate physical debilitation [22]. In this study, $68 \%$ of all study participants cases $(n=133)$ underwent either successful cardiac replacement $(n=115)$ or left-ventricular assist-device implantation $(n=18)$ after a median time on IABP support of 19 days. With the longest duration of support being 169 days, this report demonstrates that IABP can be used for an extended duration in patients awaiting HTx. However, IABP needed frequent repositioning, and $37 \%$ of study participants required replacement of the IABP due to malfunctioning. In addition, IABP support may not be helpful in advanced HF with important right-heart dysfunction as suggested by increased mortality when the ratio of atrial/pulmonary wedge pressure is high [22].

\subsection{IMPELLA}

The IMPELLA device received in 2016 Food and Drug Administration approval for use in acute myocardial infarction complicated by cardiogenic shock, but its effect on clinical outcomes has remained controversial [23]. However, IMPELLA treatment was associated with a lower mortality when compared to ECMO support in a recent retrospective propensity-matched cohort study of 6290 patients undergoing percutaneous coronary intervention for acute myocardial infarction complicated by cardiogenic shock [24]. This observation may relate to the fact that the IMPELLA increases myocardial perfusion and unloads the left ventricle, whereas the VA-ECMO increases the left ventricular afterload and, thus, may increase the infarct size and worsen clinical outcomes [25-27].

For the latter reason, the IMPELLA has been increasingly used as a temporary bridge among decompensated advanced HF patients awaiting heart transplantation [28]. However, it remains unknown whether IMPELLA treatment favorably affects outcomes in this setting.

\subsection{Venoarterial Extracorporeal Membrane Oxygenation (VA-ECMO)}

VA-ECMO remains the most utilized option for temporary MCS in patients with cardiogenic shock. It is a low-cost percutaneous device that allows for rapid implantation and provides full biventricular and pulmonary support. VA-ECMO increases the LV afterload, results in LV dilatation, and augments the incidence of thrombotic events due to stasis of the left-ventricular blood flow, which intuitively suggests an increase of adverse effects with VA-ECMO treatment. However, in the only randomized controlled trial, the ECLS-SHOCK trial, VA-ECMO treatment did not impact negatively on left-ventricular function in 30 days survivors of acute myocardial infarction complicated with cardiogenic shock [29]. In addition, the favorable neurological outcome defined as a maximal modified Rankin-score $\leq 2$ was more often in VA-ECMO-treated patients when compared to controls [30].

VA-ECMO treatment is therefore often applied in combination with left-ventricular (LV) decompression strategies such as IABP and IMPELLA treatment in order prevent LV dilatation resulting from increased LV afterload [31,32]. In fact, large meta-analyses suggest that LV decompression strategies either with IABP, IMPELLA, or left atrial or pulmonary artery cannulation is associated with lower mortality $[31,33,34]$. In accordance, 
LV decompression was likewise associated with a lower 30 day mortality in a propensitymatched cohort study while associated with an increased risk of severe bleeding, limb ischemia, and a need for renal replacement therapy [26,35]. Altogether, these results suggest a survival benefit when VA-ECMO treatment is associated with LV venting.

In summary, evidence from prospective randomized-controlled trials evaluating temporary MCS with conventional guideline-driven treatment is missing, but trials are ongoing in STEMI patients with concomitant cardiogenic shock (DOM Ger SHOCK, EUROSHOCK trial) [36,37] or cardiogenic shock without AMI (ECMO-CS, REVERSE) [38,39]. While these trials will not include all phenotypes of cardiogenic shock, their results will close, at least in part, this gap of knowledge.

\section{Long-Term Left-Ventricular Mechanical Circulatory Support (LT-MCS)}

Application of milrinone or dobutamine in advanced HF failed to show a decrease in morbidity or an increase in survival $[40,41]$. However, inotropic drug treatment may be an option in advanced HF if in accordance with the individual end-of-life care plan. Repetitive application of the inodilatator levosimendan in the outpatient setting is a promising candidate in this clinical setting [42], and the ongoing LEODOR trial (NCT03437226) compares this treatment with guidelines-directed medical therapy. While HTx still remains the most durable treatment option for eligible patients with advanced HF, the number of transplant operations remains limited to 4500 cases per year worldwide [43] and 35-50 cases per year in Switzerland [44]. HTx recipients are most often of younger age and without important comorbidity, whereas advanced HF patients are older and present with a more important comorbidity charge reason as to why they are often not considered to be suitable for HTx. This makes the case for LT-MCS implantation in the advanced HF patient who is refractory to optimal medical treatment and not eligible or opposed to HTx. This is more so true, since survival with modern continuous-flow left-ventricular assist-device (CF-LVAD) treatment has been shown to be superior to medical treatment alone in the ROADMAP-trial [45].

In theory, $10-25 \%$ of all advanced HF patients should qualify for LT-MCS treatment taking into account limitations related with age, comorbidity, or social constraint [46]. In reality, the annual implantation rate is substantially lower as indicated by a recent report from the United States [47]. On the basis of the latter report, an annual implantation rate ranging from to 100-250 may be expected in Switzerland, while, in reality, the annual implantation rate remains limited to $30-40$ patients in the last years. This large difference is surprising and suggests that the medical community still is poorly familiar with the indication for LT-MCS and the clinical profile of a potential candidate for LT-MCS implantation.

As with other treatments, the best selection of the suitable candidate is primordial for LT-MCS treatment $[48,49]$. Therefore, the current European Society of Cardiology and European Association of Cardiothoracic Surgery guidelines define the indications for LVAD implantation not only as advanced systolic HF with left-ventricular ejection fraction (LVEF) $<25 \%$ and NYHA functional class IIIb-IV despite optimal treatment. Candidates should likewise present with high one-year mortality as predicted by respective scores, by dependency on continuous intravenous inotropic support, or by fulfilling criteria indicating heart transplantation independent of whether destination therapy or HTx is the first intention $[4,50]$.

While these specifications identify potential candidates for assist-device implantation, further stratification of advanced HF into seven different levels has proven useful for evaluating the urgency of LT-MCS implantation [51]. (Table 1) This stratification is nowadays endorsed by the Interagency Registry for Mechanically Assisted Circulatory Support (INTERMACS) and the European Association of Cardio-Thoracic Surgery (EACTS) and was applied for the recruitment of study participants in clinical trials testing continuous-flow LT-MCS treatment. The majority of advanced HF patients included in these studies were in INTERMACS levels 1-4; therefore, LT-MCS treatment in these patients is based on the largest available evidence. Set out on a clinically based subdivision of patients presenting with different severity grade of advanced HF, the INTERMACS stratification has already 
been shown useful for risk stratification when revealing that the INTERMACS level 1 is associated with a significantly worse outcome with immediate LT-MCS treatment when compared to other INTERMACS levels. In consistency with this finding, patients with INTERMACS level 1 are nowadays often bridged with temporary MCS towards candidacy to long-term assist-device implantation [50].

Table 1. INTERMACS classification.

\begin{tabular}{cc}
\hline Level & Time to MCS \\
\hline $\begin{array}{c}\text { "CRASH AND BURN": critical cardiogenic shock } \\
\text { progressive decline }\end{array}$ & within hours \\
\hline $\begin{array}{c}\text { "STABLE INOTROPE-DEPENDENT": clinical stability with } \\
\text { mild to moderate dose of intravenous inotropes or patients } \\
\text { on temporary circulatory support without inotropes }\end{array}$ & within few days \\
\hline $\begin{array}{c}\text { "RECURRENT ADVANCED HEART FAILURE": "recurrent" } \\
\text { rather than "refractory" decompensation }\end{array}$ & within a few weeks \\
\hline $\begin{array}{c}\text { "EXERTION INTOLERANT": clinical stability, comfortable at } \\
\text { rest but intolerant to exercise }\end{array}$ & within weeks to months \\
\hline $\begin{array}{c}\text { "EXERTION LIMITED": clinical stability, able to do mild } \\
\text { activity but presentation of fatigue within a few minutes } \\
\text { on any meaningful physical activity }\end{array}$ & variable \\
\hline $\begin{array}{c}\text { "ADVANCED NYHA 3": clinical stability with a reasonable } \\
\text { but variable level of physical activity and without } \\
\text { recent decompensation }\end{array}$ & variable \\
\hline
\end{tabular}

For the moment, assist-device treatment in Switzerland is largely reserved for HTx candidates worsening their clinical condition towards INTERMACS level 2-4, similar to other countries. However, the largest growth in LT-MCS treatment in the last years has been seen in advanced HF patients not suitable for HTx. These DT patients present a higher burden of comorbidity when compared to BTT patients, which can explain their higher mortality [52] as shown in the prospective MOMENTUM III trial. This landmark trial showed that HM3 device treatment in BTT vs. DT study participants (197 vs. 317 patients) was associated with a higher survival rate at 1 year and 2 years after implantation (1 year: 88.8 vs. $81.5 \%$; 2 years: 76.8 vs. $73.2 \%$; respectively) [53]. Corresponding survival data were reported from one larger Swiss CF-LT-MCS cohort where in BTT patients the 1 and 2 year mortality rates were $88.4 \%$ and $84.4 \%$ at 1 and 2 years, respectively [54], while a DT patients cohort reported 87.5 and $70 \%$ survival at 1 and 2 years, respectively $(n=16)$ [55].

With the growing experience and the progressively improving performance of LT-MCS, former limitations to LT-MCS such as age, BMI, frailty, or renal dysfunction are no longer considered strict contraindications to LT-MCS treatment. In particular, $14 \%$ of LT-MCS patients were $>70$ years old in the MCS Network Research, and their unadjusted survival was $75 \%$ and $65 \%$ at 1 and 2 years, respectively, while being $84 \%$ and $73 \%$ in younger patients [56]. However, survival was no longer different when renal function was normal in the elder CF-LVAD patients [57]; therefore, age $>70$ years is no longer considered a strict limitation. Likewise, there is no cutoff of BMI above which LT-MCS is contraindicated since survival after assist device implant is not different between obese and non-obese patients, while HF readmission is more frequent in the former [58]. CF-LVAD implantation can even be applied as a BTC therapy in morbidly obese patients enabling recovery from obesity to a BMI < 35, which is the acknowledged upper limit for HTx [59]. In addition, frailty due to severe cardiac dysfunction does not longer present a contraindication since frailty may disappear with LT-MCS treatment if not resulting from cancer, lung disease, cirrhosis, liver disease, peripheral vascular, or neurological disease [60]. Renal dysfunction, although predictive for mortality after assist-device implantation [61], may also improve 
with LT-MCS treatment when secondary to reduced renal perfusion or an increase in right-atrial filling pressures. In contrast, structural kidney disease secondary to diabetes or hypertension is not likely to improve, but progression of renal dysfunction may slow with LT-MCS [50,62]. Furthermore, glycemic control may improve after restoration of normal cardiac output with LT-MCS [63], while severe end-organ damage from diabetes still remains a contraindication. Finally, preexisting pathology of coagulation may worsen after implantation of LT-MCS because of the fragmentation of the von Willebrand factor by device-related shear stress. Fortunately, the HeartMate 3 assist-device is associated with greater preservation of the macromolecular structure of the von Willebrand factor [64] suggesting that the incidence of bleeding may be lower with this device.

Despite all of this improvement, the right ventricle (RV) remains a point of concern since venous blood return will significantly increase after LT-MCS implantation, whereas unloading of the LV will induce a leftward septal shift. This results in an increase in the end-diastolic RV volume with a subsequent change in its geometry and will ultimately compromise RV function. These changes occur independent of preexisting RV function but are more likely to incidence when RV dysfunction preexists. RV dysfunction can also explain the higher incidence of postoperative bleeding, renal insufficiency, and prolonged length of hospital stay after LT-MCS implantation [65]. Preoperative identification of patients at high risk of postoperative RV failure is therefore essential, and advanced echocardiographic evaluation of the RV is recommended. However, preoperatively elevated central venous pressure (CVP) or CVP/PCWP ratio, severe renal dysfunction, and ventilator dependence are already fairly consistent predictors of severe right-ventricular failure after LT-MCS implantation [66]. Less-invasive surgery for LT-MCS placement when compared with conventional median sternotomy may be associated with a reduced incidence of RV failure after LT-MCS implantation as suggested from an international multicenter retrospective cohort [67]. This beneficial effect may relate to the fact that less-invasive surgery preserves pericardial constraint and, thus, better maintains LV twist and longitudinal septal motion [68]. However, this observation affords prospective testing in order to show whether this technique is an option for patients with a high risk for postoperative RV failure. In the future, robotic surgery may represent another noteworthy approach not only because it is a sternotomy sparing approach but also because it should maintain pericardial constraint. However, so far, only case-experience is reported $[69,70]$.

In the past, more important RV dysfunction was considered a contraindication to LT-MCS. However, post-operative right-ventricular-acute MCS (RV-AMCS) devices have become more commonly used in the clinical setting of pre-operative RV dysfunction. Furthermore, designated algorithms help to select the proper device and provide recommendations for patient monitoring and weaning protocols [71]. In the case of unlikely recovery of RV dysfunction after LV LT-MCS implantation, a biventricular setup of continuousflow VADs has been utilized. This therapeutic approach is complicated by a high rate of pump thrombosis [72]; therefore, implantation of a total artificial heart (THA) remains a valid option. Candidates for TAH are most often considered when HTx candidates suffer from acute irreversible biventricular failure at high risk for imminent death (INTERMACS class 1 or 2) and for whom a suitable donor is not available. The miniaturization of the console permits ambulation and aggressive physiotherapy, and this main benefit can explain why $60 \%$ of patients on TAH support at HTx present an overall 1-year survival posttransplant rate of $70 \%$ [73].

Finally, aortic-valve regurgitation affords careful evaluation since $>$ mild aortic regurgitation mandates biological valve placement or application of a central leaflet coaptation stitch. However, both approaches increase the perioperative risk of RV dysfunction due to the need of extracorporeal circulation support in the operating room. However, $>$ mild AR affords pre-implantation intervention because an increase in the severity of aortic regurgitation will result in a circulatory short-circuit between the CF-LVAD, the ascending aorta, and the left ventricle. Furthermore, a mechanic aortic prosthesis should be replaced by an aortic bioprosthesis, while a functional aortic bioprosthesis can remain in place [14]. 
In summary, the arrival of the last generation of continuous-flow LT-MCS together with the experience gained in the last years has expanded the pool of advanced HF patients who will benefit from LT-MCS treatment taking into account the remaining limitations (Figure 1).

Central table

Progress of Surgical Options in Advanced heart failure

\begin{tabular}{l}
\hline TEMPORARY MECHANICAL CIRCULATORY SUPPORT \\
Intraaortic ballon pump \\
improves waitlist outcomes \\
axillary position permits extended treatment \\
duration \\
IMPELLA \\
associated with lower mortality in acute \\
myocardial infarction with cardiogenic shock when \\
compared with VA-ECMO \\
increasingly used as temporary bridge in patients \\
awaiting heart transplantation \\
Veno-arterial ECMO \\
- meta-analysis shows that LV decompression \\
strategies (IMPELLA. IABP) decrease mortality \\
randomized-controlled trials evaluating VA-ECMO \\
in cardiogenic shock are ongoing
\end{tabular}

\begin{tabular}{|l|}
\hline LONG-TERM MECHANICAL CIRCULATORY SUPPORT \\
- HeartMate 3 treatment is associated with \\
excellent 1-vear and 2-vears survival in young and \\
older advanced heart failure patients \\
- High BMI, frailty for cardiac reason, and moderate \\
renal dysfunction or diabetes may improve with \\
LT-MCS treatment \\
- Right ventricular dysfunction and >mild aortic \\
valve insufficiency afford careful evaluation before \\
LT-MCS implantation \\
- Better preservation of the macromolecular \\
structure of the von Willbrand factor suggests a \\
lower incidence of bleeding with HeartMate 3 \\
treatment \\
- Allosensitization in BTT patients affords \\
individualized desensitization strategies
\end{tabular}

- HEART TRANSPLANTATION
- Improvement of matching algorithms between
donor and recipient may decrease the number of
donor hearts refused for mismatch
- Preservation of the donor heart with the
SherpaPAk $k^{T M}$ promises to reduce cold ischemia
related donor heart damage.
- continuous, normothermic perfusion with warm,
oxvgenated, nutrient-enriched donor blood using
the Organ Care SystemTM promises solutions for
long distance transport and may help to expand of
the donor pool
- Allosensitization is frequent in BTT patients and
affords individualized treatment strategies
- HTx recipients with pretransplant allosensitization
afford close follow-up

HTx

Age $>70$ years

$>$ Moderate AR

ventricular arrythmia

renal dysfunction

$>$ Child A liver cirrhosis

acute bacterial infection

chronic viral infection

genetic bleeding disorder

psychosocial difficulty

>moderate RV dysfunction

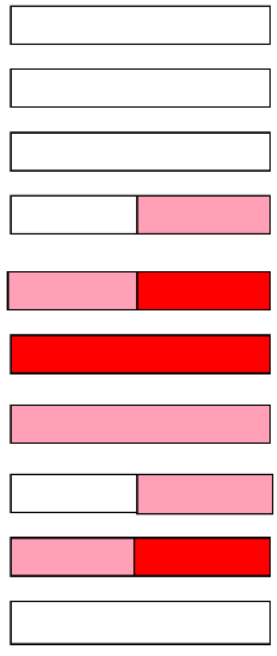

relative contraindication
LT-MCS

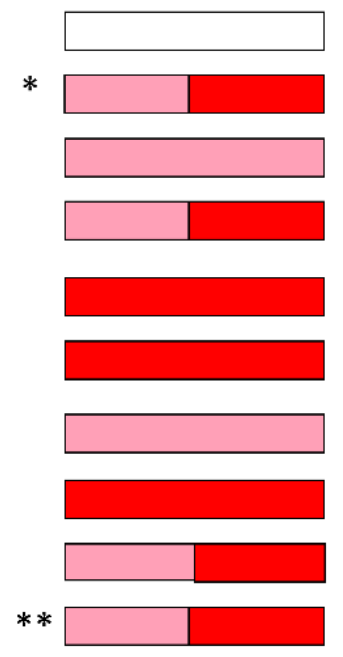

absolute contraindication

no contraindication

Figure 1. Indication, relative and absolute contraindications for temporary RV-AMCS, LT-MCS, and HTx. AR=aortic regurgitation; * mild AR = relative contraindication; >mild AR = absolute contraindication, aortic-valve replacement with bioprothesis is recommended; ${ }^{* *}$ mild RV dysfunction = relative contraindication; > mild RV = consider perioperative strategies with LV or LT-MCS (see Kapur et al.; Farag et al.; Noly et al.); all indications or relative/absolute contraindications (see Costanzo M.R., Dipchand A., Starling R., et al. The International Society of Heart and Lung Transplantation Guidelines for the care of heart transplant reciepients. J. Heart Lung. Transplant, 2010, 29, 915-955; Gustafsson F, Rogers JG. Eur J Heart Fail, 2017, 19, 595-602. 


\section{Heart Transplantation}

Heart transplantation (HTx) remains nonetheless the gold-standard treatment for advanced heart failure treatment despite the favorable results of durable MCS with recent continuous-flow LT-MCS [74]. The fact that the number of patients on the waiting list in the U.S. has increased by $37 \%$ in the years 2009 to 2018 may provide support to the statement that HTx remains nonetheless the superior choice for surgical treatment of advanced HF. However, this increase concomits with a progressive increase in the number of patients with cardiomyopathy of non-ischemic origin, while the number of patients with ischemic cardiomyopathy has remained largely unchanged [75]. Cardiomyopathy of non-ischemic origin often presents with right-ventricular dysfunction, which may prohibit left-ventricular LT-MCS [14], and this can explain the increase in HTx candidates on the U.S. waitlist. In contrast to the U.S., the numbers of patients on the waitlist in Switzerland have remained virtually unchanged from 2016 to 2020 [44]. Moreover, in a Swiss HTx center the number of patients with HTx for end-stage dilated cardiomyopathy of non-ischemic origin has decreased to $42.7 \%$, while the number of end-stage HF patients due to ischemic cardiomyopathy has increased to $39.3 \%$ [76].

These antidromic developments may result from differences in the waitlist policy. In fact, the U.S. replaced more recently their long-standing three-tier system by a sixtier system based on the deliberation that increased granularity should improve waitlist grading of HF severity, and, thus, better identify the HTx candidate in need of urgent transplantation [77]. The waitlist policy has changed in Switzerland as well; however, the number of transplant operations in urgency status was sanctioned to an agreed maximum number of about $25 \%$ of all transplant operations, intending to reduce the disadvantage for patients on the normal waitlist. By this strategy, the number of HTx in urgency remained limited to 27-32\% of all HTx operations in the years 2016-2020 [44] without an overall effect on one-year outcomes [76]. The six-tier system likewise did not affect one-year outcomes after HTx in the U.S. [78]; however, comparison on the basis of mortality alone remains insufficient since other parameters of post-transplant success such as time out of the hospital, freedom from dialysis, and improvement in physical and cognitive frailty are necessary to obtain a more-holistic view on the contemporary HTx waitlist policy.

Care for congenital heart disease (CHD) has significantly improved in the last decades with more than $90 \%$ of children born with these defects surviving until adulthood. HF is the leading cause of death in the majority of these adult patients, and more and more CHD are candidates for HTx [79] with beneficial long-term results [80]. However, LT-MCS is a valid option if a donor heart is not readily available [81,82].

Despite the clear need for an increased number of donor organs, the utilization rate of donor hearts has remained fairly low worldwide. The reasons for refusal of donor hearts in the U.S. have been a size mismatch, histo-incompatibility, older age, female donor gender, or donor-comorbidities [83]. Guidelines have traditionally recommended against donor undersizing by weight, especially for female donors [84]. Therefore, in an effort to improve size-matching metrics, various anthropometric parameters were tested for prediction of matching sorting heart mass as a superior predictor. In fact, undersizing of the donor organ based on heart mass matching was associated with increased mortality in a retrospective analysis of 19,168 HTx recipients in the UNOS data base (HR 1.34; 95\% CI 1.13-1.59; $p<0.001$ ) [85]. On the other hand, $32 \%$ of the donor hearts that were declined due to concerns of undersizing in the UNOS database of the years 2007 to 2016 were found eligible when using the heart mass as a parameter for matching metrics. While these results promise to improve the allocation of female donor hearts, a smaller study of 288 HTx recipients showed that undersizing of the donor heart affects early hemodynamics but was without impact on one-year survival [86]. Altogether, these results suggest that efforts to improve matching metrics have the potential to increase the allocation of donor organs judged not suitable based on current recommendations.

The number of HTx candidiates with allosensitization at a high titer of pre-formed HLA-antibodies has doubled over the last decades $[43,87]$ and becomes more and more 
an obstacle to donor heart allocation. It affects between $6 \%$ to $9.2 \%$ of all HTx candidates, and while an earlier series of patients on LT-MCS reported a prevalence of allosensitization in up to two thirds of their patients [88], a contemporary series indicates a lower rate of $11 \%$ in patients on pulsatile LT-MCS and $15 \%$ in those on continuous-flow support [89]. However, allosensitization represents a threat to HTx programs since the number of BTT patients on the waitlist is increasing [76]. Furthermore, allosensitization decreases not only the potential donor pool for a given candidate but also prolongs the time on the waitlist. The allosensitized patient also faces an increased incidence of acute rejection and an overall worse survival posttransplant [90] despite the fact that the preformed antibodies at lowtiter are considered safe for HTx in the immediate and early postoperative phase [91]. Traditional desensitization protocols as well as emerging therapies can be successfully trialed in the appropriate HTx candidate in order to reduce the number and the level of preformed antibodies and to increase transplant eligibility [92-94]. However, pretransplant desensitization protocols in the LT-MCS patient are not without risk particularly for cable infection [95]. Additionally, posttransplant strategies for prevention of humoral rejection may be beneficial in the short-term as shown more recently in a trial applying rituximab treatment within the first 12 postoperative days. However, rituximab application was associated in this trial with a marked increase in the atheroma burden in the cardiac allograft [96] questioning the mid-and long-term benefits of this treatment. However, a case series of HTx recipients with a humoral rejection posttransplant was shown to benefit from a complement blockade [97], suggesting that this therapeutic strategy may also apply for HTx of allosensitized patients.

Preservation and storage of the donor organ has become an important issue in today's allocation since traveling distances are larger, prolonging cold ischemic times. In order to decrease myocardial damage from the unmet metabolic need during transport, a cardioplegic solution is applied at procurement to induce diastolic arrest. In addition, hypothermia during transport is maintained until reperfusion in the recipient [98]. Traditionally, hypothermia during transport is maintained by the use of ice externally cooling the pouch, which contains the donor heart in the transport medium [99]. However, an absent temperature control risks to expose, in particular, the thin-walled RV of the cardiac allograft to very low temperature conditions, which may result in primary graft dysfunction. In 2018, the Paragonix SherpaPak ${ }^{\mathrm{TM}}$, which maintains a target temperature and avoids placing the donor organ in close proximity to ice, was presented [100]. Case reports suggest that the SherpaPak ${ }^{\mathrm{TM}}$ enables longer cold ischemic transport times [101], however, controlled studies are mandated until broader application with a prolonged ischemia time can be recommended. Therefore, and until provision of further evidence, a maximal duration of 4 hours of cold ischemia time should be respected even in younger-age donors [102].

In recent years, continuous, normothermic perfusion with warm, oxygenated, nutrientenriched donor blood provided by the TransMedics Organ Care System (OCS) ${ }^{\mathrm{TM}}$ has been evaluated as another option for the transport of the donor organ to the recipient. The monitoring of the donor graft function is possible via visual inspection of the donor heart, measurement of the coronary blood flow, and serial arterial or venous lactate measurements. The PROCEED II trial (Randomized Study of Organ Care System Cardiac Preservation for Preservation of Donated Hearts for Eventual Transplantation) randomized 130 patients to standard cold storage or the OCS ${ }^{\mathrm{TM}}$, and the results showed non-inferiority for the latter without a difference in 30 day patient and graft survival [103]. Of note, the total mean out-of-body time was longer, while the cold ischemia was shorter. This suggests that a longer transport time is feasible with the $\mathrm{OCS}^{\mathrm{TM}}$ without increasing the risk of cardiacrelated serious adverse events. The OCS has also been tested for the use of extended criteria donors in the OCS Heart EXPAND trial. Donor hearts in this study were of older donor age, presented left-ventricular dysfunction or hypertrophy, or were donor hearts after prolonged cardiac arrest, exposed to prior drug abuse, or presenting mild to moderate coronary disease. Application of the OCS resulted in an excellent short-term post-transplant survival ( $88 \%$ six-month survival) and low rates of primary graft dysfunction $(10.7 \%$ rate 
of severe left- or right-ventricular dysfunction at 24 hours posttransplant) [104]. Another study compared the outcome of HTx with marginal donor hearts preserved by ex vivo normothermic perfusion $(n=26)$ or cold storage $(n=79)$. A total of $21 / 26$ marginal donor hearts preserved by OCS ${ }^{\mathrm{TM}}$ were successfully transplanted with 5/26 donor hearts discarded because considered unsuitable while on the OCS ${ }^{\text {TM }}$. These 21 patients presented an overall lower burden of postoperative complications when compared to control-group marginal donor hearts preserved by cold storage [105]. Altogether, the results from the latter studies suggest that ex vivo normothermic perfusion permits appraisal of marginal donor heart function and has the potential to exclude non-suitable marginal donor grafts from transplantation. Notably, marginal donor hearts considered suitable for transplantation on the OCS ${ }^{\mathrm{TM}}$ had favorable short-term results after HTx. However, knowledgeable care of the ex vivo organ is primordial, and this is only provided with routine application of OCS ${ }^{\mathrm{TM}}$ based preservation. In Switzerland, application of the $\mathrm{OCS}^{\mathrm{TM}}$ faces financial limitations at the moment, especially because of expensive consumables. However, transport times up to 10 hours with successful subsequent HTx have been reported when donor hearts were procured and preserved using this technique [106,107]. Therefore, this system promises to provide solutions not only for procurement of donor hearts at large distance but also for the expansion of the donor heart pool.

In summary, a recent advance in the field of cardiac transplantation provides solutions for the growing demand for suitable organs. Improved size matching considering the heart mass has the potential to improve donor-recipient matching and to reduce the refusal rate based on mismatches of height, body weight, and gender, thereby expanding the donor pool. Furthermore, an advance in organ preservation permits not only procurement at larger distances but also ex vivo appraisal of the function of the donor heart meeting extended criteria for procurement with the potential to increase the number of donor hearts suitable for transplantation. The future of cardiac transplantation will rely on these advances so that a maximum of heart transplant recipients has the chance to derive the best quality of life and survival.

\section{Taking Care of the Aged Advanced Heart Failure Patient in the French-Speaking Part of Switzerland}

Since 2003, the University Hospitals of Geneva and Lausanne have collaborated in a common HTx program with the transplant operation and the immediate postoperative care provided by the latter hospital. In this context, the two centers have agreed on an algorithm paving the treatment of the advanced HF patient $>65$ years of age. Acknowledging that the indications for surgical care of the younger advanced HF patient are set out clearly by the International Society of Heart and Lung Transplantation and the European Association of Cardiothoracic Surgery $[13,108]$, these were not taken into consideration by this algorithm (Figure 2).

The 10 year update of the listing criteria for HTx recommends that advanced HF patients can be considered for HTx if they are $<71$ years of age, while HTx remains an option in selected patients $>70$ years [108]. The overall consensus in Switzerland and in the present algorithm is that advanced HF patients can be waitlisted until the age of 65 years when meeting the listing criteria and if an absolute contraindication is absent. However, the option of HTx is only provided if the individual patient presents with INTERMACS class 5 to 7 promising survival until the transplant operation $[4,108]$. The Swiss consensus for HTx in advanced HF patients between 65-69 years old limits the option of HTx waitlisting to patients with cardiac monopathology and without larger additional comorbidity. In any case, urgent HTx is not an option when the clinical conditions of these patients decline (Figure 2). Furthermore, these HTx candidates are preferentially considered for extendedcriteria donor hearts acknowledging that the one-year and five-year survival rates are not different if extended-criteria donor hearts are used as shown more recently in an analysis of the Scientific Registry of Transplant Recipients [109]. Therefore, these recipients are not competing with younger patients on the waitlist. In Switzerland, only $27.5 \%$ of all donor 
heart offers ( $n=199 / 723$ ) were transplanted in the years 2007-2013, and the mean age was 40.2 years [110], suggesting that application of extended criteria may expand the donor heart pool only by considering older-age donor hearts for transplantation. In addition, the results from the extended-criteria donor hearts evaluated by the OCS ${ }^{\mathrm{TM}}$ indicate that expansion of the donor heart pool beyond older age and by inclusion of donor heart with structural pathology is possible [105].

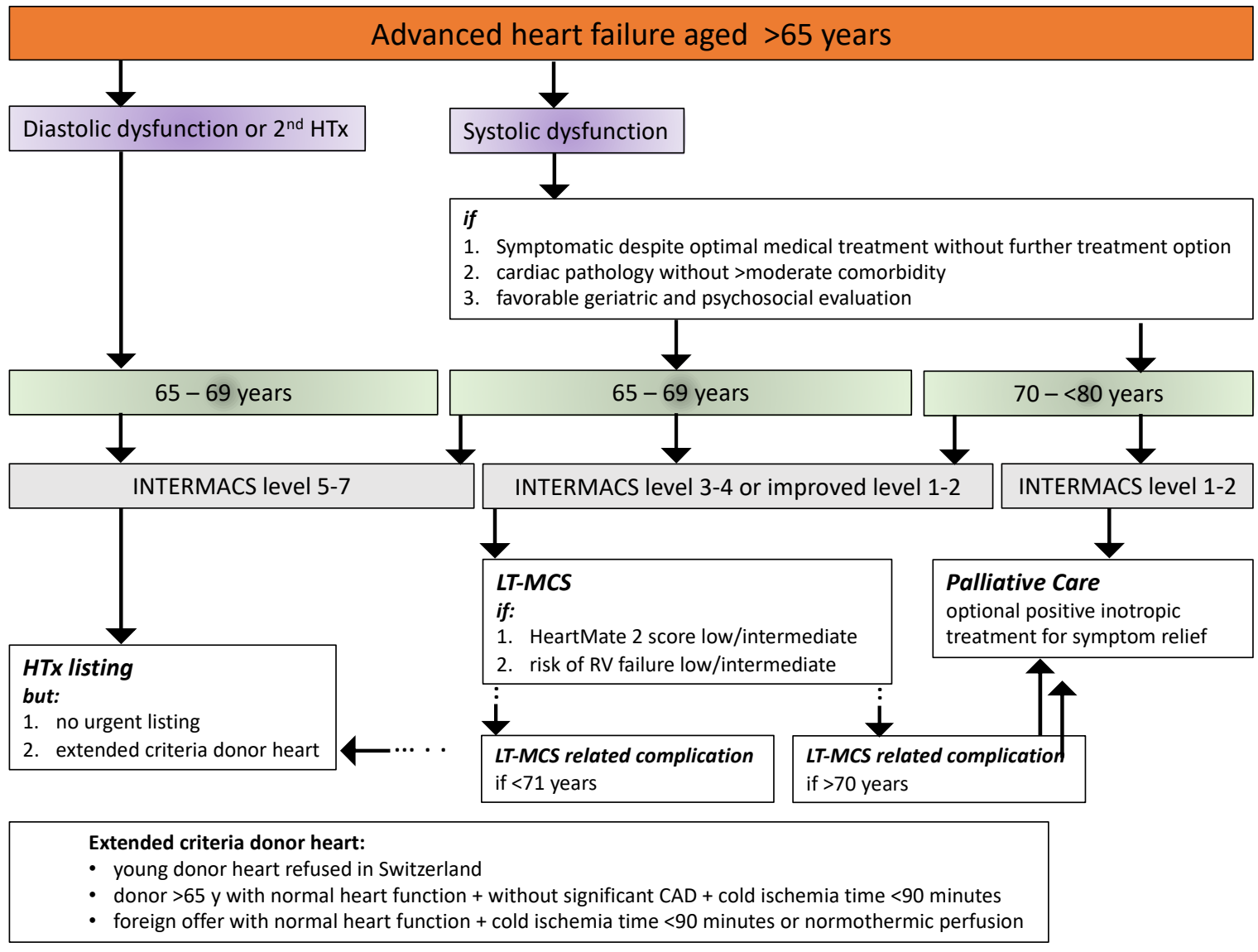

Figure 2. Algorithm describing the care of the aged patient with advanced heart failure in the French-speaking part of Switzerland.

Nonetheless, the usual option of surgical treatment of an advanced HF patient aged between 65-69 years is DT (Figure 2), especially if an advanced HF patient presents with INTERMACS class 3 and 4. The decision in favor of LT-MCS is furthermore fostered when the HeartMate 2 risk score [111], and evaluation of RV predicts a favorable outcome [66]. If these LT-MCS patients at the age of 65-69 years experience associated incurable complications such as recurrent episodes of ventricular storm or severe gastrointestinal bleeding, progressive aortic-valve insufficiency, or device-related severe infection, the algorithm provides the option for HTx but again without the possibility for urgent HTx. HTx is also not an option if LT-MCS patients are $>70$ years of age where optimal medical treatment or palliative treatment are foreseen in accordance with the end-of-life plan of the individual patient.

\section{Conclusions}

The arrival of the last generation of continuous-flow LT-MCS and the experience gained in the last years has increased the number of advanced HF patients eligible for LTMCS treatment. This evolution is of importance in particular because of the progressively increasing number of advanced HF patients presenting with older age where HTx does remain an option for highly selected cases. However, the improvement in matching metrics 
between donors and recipients has the potential to expand the donor pool, resulting in transplantation for otherwise-refused donor hearts. In addition, recent development of organ preservation permits not only procurement at larger distances but also appraisal of extended-criteria donor hearts and, thus, has the potential to increase the number of donor hearts suitable for transplantation. Therefore, there is promise that more patients with advanced HF may have the benefit of surgical treatment of advanced HF already in the near future.

Author Contributions: R.H. drafted and wrote this narative review. P.M., P.Y. and M.K. contributed largely to the establishment of the algorythm describing the care of the aged patient with advanced heart failure. All authors have read and agreed to the published version of the manuscript.

Funding: This research received no external funding.

Institutional Review Board Statement: Not applicable.

Informed Consent Statement: Not applicable.

Data Availability Statement: Not applicable.

Conflicts of Interest: The authors declare no conflict of interest.

\section{References}

1. Crespo-Leiro, M.G.; Anker, S.D.; Maggioni, A.P.; Milicic, D.; Costanzo, M.R.; Filippatos, G.; Gustafsson, F.; Tsui, S.; BargeCaballero, E.; De Jonge, N.; et al. European Society of Cardiology Heart Failure Long-Term Registry (ESC-HF-LT): 1-year follow-up outcomes and differences across regions: ESC-HF-LT: 1-year follow-up. Eur. J. Heart Fail. 2016, 18, 613-625. [CrossRef] [PubMed]

2. Xanthakis, V.; Enserro, D.M.; Larson, M.G.; Wollert, K.C.; Januzzi, J.L.; Levy, D.; Aragam, J.; Benjamin, E.J.; Cheng, S. Prevalence, Neurohormonal Correlates, and Prognosis of Heart Failure Stages in the Community. JACC Heart Fail. 2016, 4, 808-815. [CrossRef] [PubMed]

3. Shah, A.M.; Claggett, B.; Loehr, L.; Chang, P.P.; Matsushita, K.; Kitzman, D.; Konety, S.; Kucharska-Newton, A.; Sueta, C.A.; Mosley, T.H.; et al. Heart Failure Stages Among Older Adults in the Community. Circulation 2017, 135, 224-240. [CrossRef] [PubMed]

4. McDonagh, T.A.; Metra, M.; Adamo, M.; Gardner, R.S.; Bauchmach, A.; Bohm, B.; Burri, H.; Butler, J.; Celutkiene, J.; Chioncel, O; et al. 2021 ESC guidelines for the diagnosis and treatment of acute and chronic heart failure. Eur. J. Heart 2021, 42, 1-128. [CrossRef]

5. Abdurashidova, T.; Monney, P.; Tzimas, G.; Soborun, N.; Regamey, J.; Daux, A.; Barras, N.; Kirsch, M.; Müller, M.; Hullin, R. Non-severe aortic regurgitation increases short-term mortality in acute heart failure with preserved ejection fraction. ESC Heart Fail. 2020, 7, 3901-3909. [CrossRef]

6. Yaku, H.; Ozasa, N.; Morimoto, T.; Inuzuta, Y.; Tamaki, A.; Yamatoto, Y.; Yoshikwaka, Y.; Kitai, T.; Tanighuci, R.; Jinnai, T.; et al. Demographics, management, and in-hospital outcome of hospitalized acute heart failure patients in contemporary real clinical practice in Japan. Circ. J. 2018, 82, 2811-2819. [CrossRef]

7. Ambrosy, A.P.; Fonarow, G.C.; Butler, J.; Chioncel, O.; Greene, S.J.; Vaduganathan, M.; Nodari, S.; Lam, C.S.; Sato, N.; Shah, A.N.; et al. The Global Health and Economic Burden of Hospitalizations for Heart Failure. J. Am. Coll. Cardiol. 2014, 63, 1123-1133. [CrossRef]

8. Crespo-Leiro, M.G.; Metra, M.; Lund, L.H.; Milicic, D.; Costanzo, M.R.; Filippatos, G.; Gustafsson, F.; Tsui, S.; Barge-Caballero, E.; De Jonge, N.; et al. Advanced heart failure: A position statement of the Heart Failure Association of the European Society of Cardiology. Eur. J. Heart Fail. 2018, 20, 1505-1535. [CrossRef]

9. German Heart Society. Deutscher Herzbericht 2017 Sektoren Uebergreifende Versorgungsanalyse zur Kardiologie, Herz-Chirurgie und Kinderherzmedizin; Deutschland. e.V. DH: Frankfurt, Germany, 2017.

10. Maack, C.; Eschenhagen, T.; Hamdani, N.; Heinzel, F.R.; Lyon, A.R.; Manstein, D.J.; Metzger, J.; Papp, Z.; Tocchetti, C.G.; Yilmaz, M.B.; et al. Treatments targeting inotropy. Eur. Heart J. 2018, 40, 3626-3644. [CrossRef]

11. Ahmad, T.; Miller, P.E.; McCullough, M.; Desai, N.R.; Riello, R.; Psotka, M.; Böhm, M.; Allen, L.A.; Teerlink, J.R.; Rosano, G.M.; et al. Why has positive inotropy failed in chronic heart failure? Lessons from prior inotrope trials. Eur. J. Heart Fail. 2019, 21, 1064-1078. [CrossRef]

12. Barge-Caballero, E.; Almenar-Bonet, L.; Gonzalez-Vilchez, F.; Rodríguez, J.L.L.; González-Costello, J.; Segovia-Cubero, J.; Castel-Lavilla, M.A.; Jiménez, J.F.D.; Garrido-Bravo, I.P.; Rangel-Sousa, D.; et al. Clinical outcomes of temporary mechanical circulatory support as a direct bridge to heart transplantation: A nationwide Spanish registry. Eur. J. Heart Fail. 2017, 20, 178-186. [CrossRef] [PubMed] 
13. Finnan, M.J.; Bakir, N.H.; Itoh, A.; Kotkar, K.D.; Pasque, M.K.; Damiano, R.J.; Moon, M.R.; Ewald, G.A.; Schilling, J.D.; Masood, M.F. 30 Years of Heart Transplant: Outcomes After Mechanical Circulatory Support From a Single Center. Ann. Thorac. Surg. 2021, 113, 41-48. [CrossRef] [PubMed]

14. Potapov, E.V.; Antonides, C.; Crespo-Leiro, M.G.; Hannan, M.G.; Kuckucka, M.; de Jonge, N.; Loforte, A.; Lund, L.; Mohacsi, P.; Morshuis, M.; et al. 2019 EATCS expert consensus on long-term mechanical circulatory support. Eur. J. Cardio Thor. Surg. 2019, 56, 230-270. [CrossRef] [PubMed]

15. Freund, A.; Desch, S.; Thiele, H. Intra-aortic balloon counterpulsation-Does it work? Prog. Cardiovasc. Dis. 2020, 63, 623-629. [CrossRef] [PubMed]

16. O'Neill, W.W.; Kleiman, N.S.; Moses, J.; Henriques, J.P.; Dixon, S.; Massaro, J.; Palacois, I.; Maini, B.; Mulukatla, S. A prospective, randomized clinical trial of hemodynamic support with Impella 2.5 versus intra-aortic balloon pump in patients undergoing high-risk percutaneous coronary intervention: The PROTECT II study. Circulation 2012, 126, 1717-1727. [CrossRef] [PubMed]

17. Thiele, H.; Zeymer, U.; Neumann, F.-J.; Ferenc, M.; Olbrich, H.-G.; Hausleiter, J.; Richardt, G.; Hennersdorf, M.; Empen, K.; Fuernau, G.; et al. Intraaortic Balloon Support for Myocardial Infarction with Cardiogenic Shock. N. Engl. J. Med. 2012, 367, 1287-1296. [CrossRef] [PubMed]

18. Thiele, H.; Zeymer, U.; Thelemann, N.; Neumann, F.-J.; Hauseleiter, J.; Abdel-Wahab, M.; Meyer-Sarei, R.; Fuernau, G.; Eitel, J.; Hambrecht, R.; et al. Intraaortic balloon pump in cardio-Genic shock complicating acute myocardial infarction: Long-term 6-year out- come of the randomized IABP-SHOCK II Trial. Circulation 2019, 139, 395-403. [CrossRef]

19. Patel, M.R.; Smalling, R.W.; Thiele, H.; Huiman, X.; Zhou, Y.; Chandra, P.; Chew, D.; Cohen, D.; French, J.; Perera, D.; et al. Intra-aortic balloon counterpulsation and infarct size in patients with acute ante-rior myocardial infarction without shock: The CRISP AMI randomized trial. JAMA 2011, 306, 1329-1337. [CrossRef]

20. Dhruva, S.S.; Ross, J.R.; Mortazavi, B.J.; Hurlay, N.Z.; Krumholz, H.M.; Curtis, J.P.; Berkowitz, A.P.; Masoudi, F.A.; Messenger, J.C.; Parzynski, C.S.; et al. Association of Use of an Intravascular Microaxial Left Ventricular Assist Device vs Intra-aortic Balloon Pump With In-Hospital Mortality and Major Bleeding Among Patients With Acute Myocardial Infarc-tion Complicated by Cardiogenic Shock. JAMA 2020, 323, 734-745. [CrossRef]

21. Huckaby, L.V.; Seese, L.M.; Mathier, M.A.; Hickey, G.W.; Kilic, A. Intra-aortic balloon pump bridging to heart transplantation: Impact of the 2018 allocation change. Circ. Heart Fail. 2020, 13, 206-213. [CrossRef]

22. Bhimaraj, A.; Agrawal, T.; Duran, A.; Tamimi, O.; Amione-Guerra, J.; Trachtenberg, B.; Guha, A.; Hussain, I.; Kim, J.; Kassi, M.; et al. Percutaneous left axillary artery placement of intra-aortic balloon pump in advanced heart failure patients. JACC Heart Fail. 2020, 8, 313-323. [CrossRef] [PubMed]

23. Amin, A.P.; Spertus, J.A.; Curtis, J.P.; Desai, N.; Masoudi, F.A.; Bach, R.G.; McNeely, C.; Al-Badarin, F.; House, J.A.; Kulkarni, H.; et al. The evolving landscape of Impella use in the United States among patients under-going percutaneous coronary intervention with mechanical circulatory support. Circulation 2020, 141, 273-284. [CrossRef] [PubMed]

24. Lemor, A.; Hosseini Dehkordi, S.H.; Basir, M.B.; Villablanca, P.A.; Jain, T.; Koenig, G.C.; Alaswad, K.; Moses, J.W.; Kapur, N.K.; O'Neill, W. Impella versus extracorporeal membrane oxygenation for acute myocar-dial infarction cardiogenic shock. Cardiovasc. Revasc. Med. 2020, 21, 1465-1471. [CrossRef] [PubMed]

25. Swain, L.; Reyelt, L.; Bhave, S.; Qiao, X.; Thomas, C.J.; Zweck, E.; Crowley, P.; Boggins, C.; Esposito, M.; Chin, M.; et al Transvalvular Ventricular Unloading Before Reperfusion in Acute Myocardial Infarction. J. Am. Coll. Cardiol. 2020, 76, 684-699. [CrossRef]

26. Schrage, B.; Becher, P.M.; Bernhardt, A.; Bezerra, H.; Blankenberg, S.; Brunner, S.; Colson, P.; Cudemus Deseda, G.; Dabboura, S.; Eckner, D.; et al. Left ventricular unloading is associated with lower mortality in patients with cardiogenic shock treated with venoarterial extracorporeal membrane oxygenation: Results from an international, multicenter cohort study. Circulation 2020, 142, 2095-2106. [CrossRef]

27. Bastos, M.B.; Burkhoff, D.; Maly, J.; Daemen, J.; den Uil, C.; Amelot, K.; Lenzen, M.; Mahfoud, F.; Zijlstra, F.; Schreuder, J.J.; et al Invasive left ventricle pressure-volume analysis: Overview and practical clinical im-plications. Eur. Heart J. 2020, 41, $1286-1297$. [CrossRef]

28. Varshney, A.S.; Berg, D.D.; Katz, J.N.; Baird-Zars, V.M.; Bohula, E.A.; Carnicelli, A.P.; Chaudhry, S.-P.; Guo, J.; Lawler, P.R.; Nativi-Nicolau, J.; et al. Use of Temporary Mechanical Circulatory Support for Management of Cardiogenic Shock Before and After the United Network for Organ Sharing Donor Heart Allocation System Changes. JAMA Cardiol. 2020, 5, 703-708. [CrossRef]

29. Brunner, S.; Guenther, S.P.W.; Lackermair, K.; Peterss, S.; Orban, M.; Boulesteix, A.L.; Michel, S.; Hausleiter, J.; Massberg, S.; Hagl, C. Extracorporeal life support in cardiogenic shock complicating acute myo-cardial infarction. J. Am. Coll. Cardiol. 2019, 73, 2355-2357. [CrossRef]

30. Lackermair, K.; Brunner, S.; Orban, M.; Peterss, S.; Orban, M.; Theiss, H.D.; Huber, B.C.; Juchem, G.; Born, F.; Boulesteix, A.-L.; et al. Outcome of patients treated with extracorporeal life support in cardiogenic shock complicating acute myocardial infarction: 1-year result from the ECLS-Shock study. Clin. Res. Cardiol. 2020, 110, 1412-1420. [CrossRef]

31. Russo, J.J.; Aleksova, N.; Pitcher, I.; Couture, E.; Parlow, S.; Faraz, M.; Visintini, S.; Simard, T.; Di Santo, P.; Mathew, R.; et al. Left Ventricular Unloading During Extracorporeal Membrane Oxygenation in Patients With Cardiogenic Shock. J. Am. Coll. Cardiol. 2019, 73, 654-662. [CrossRef]

32. Donker, D.W.; Brodie, D.; Henriques, J.P.S.; Broomé, M. Left ventricular unloading during veno-arterial ECMO: A review of per-cutaneous and surgical unloading interventions. Perfusion 2019, 34, 98-105. [CrossRef] [PubMed] 
33. Char, S.; Fried, J.; Melehy, A.; Mehta, S.; Ning, Y.; Kurlansky, P.; Takeda, K. Clinical efficacy of direct and indirect left ventricular unloading during venoarterial extracorporeal membrane oxygenation for primary cardiogenic shock. J. Thoracic. Cardiovasc. Surg. 2021. [CrossRef] [PubMed]

34. Al-Fares, A.A.; Randhawa, V.K.; Englesakis, M.; McDomald, M.A.; Nagpal, A.D.; Estep, J.D.; Soltesz, E.G.; Fan, E. Optimal strategy and timing of left ventricular venting during veno-arterial extracorporeal life support for adults in cardiogenic shock: A systematic review and meta-analysis. Circul. Heart Fail. 2019, 12, 1-16. [CrossRef] [PubMed]

35. Lüsebrink, E.; Orban, M.; Kupka, D.; Scherer, C.; Hagl, C.; Zimmer, S.; Luedike, P.; Thiele, H.; Westermann, D.; Massberg, S.; et al. Prevention and treatment of pulmonary congestion in patients undergoing venoarterial extracorporeal membrane oxygenation for cardiogenic shock. Eur. Heart J. 2020, 41, 3753-3761. [CrossRef]

36. Udesen, N.J.; Møller, J.E.; Lindholm, M.G.; Eiskjær, H.; Schäfer, A.; Werner, N.; Holmvang, L.; Terkelsen, C.J.; Jensen, L.O.; Junker, A.; et al. Rationale and design of DanGer shock: Danish-German cardiogenic shock trial. Am. Heart J. 2019, $214,60-68$. [CrossRef]

37. Testing the Value of Novel Strategy and its Cost Efficacy in Order to Improve the Poor Outcomes in Cardiogenic ShockTabular View-ClinicalTrials.gov. Available online: https://clinicaltrials.gov/ct2/show/record/NCT03813134 (accessed on 23 November 2021).

38. Ostadal, P.; Rokyta, R.; Kruger, A.; Vondrakova, D.; Janotka, M.; Šmíd, O.; Šmalcová, J.; Hromadka, M.; Linhart, A.; Bělohlávek, J. Extra corporeal membrane oxygenation in the therapy of cardiogenic shock (ECMO-CS): Rationale and design of the multicenter randomized trial. Eur. J. Heart Fail. 2017, 19, 124-127. [CrossRef]

39. Ibrahim, M. A prospective randomised trial of early LV venting using Impella CP for recovery in patients with cardiogenic shock managed with VA ECMO. ClinicalTrials.gov. 2020. Available online: https://clinicaltrials.gov/ct2/show/NCT03431467 (accessed on 29 November 2021).

40. Felker, G.M.; Benza, R.L.; Chandler, A.B. Heart failure etiology and response to milrinone in decompensated heart fail-ure: Results from the OPTIME-CHF study. J. Am. Coll. Cardiol. 2003, 41, 997-1003. [CrossRef]

41. Bonios, M.J.; Terrovitis, J.V.; Drakos, S.G.; Katsaros, F.; Pantsios, C.; Nanas, S.N.; Kanakadis, J.; Alexopoulos, G.; Toumanidis, S.; Anastasiou-Nana, M.; et al. Comparison of three different regimens of intermittent inotrope infusions for end stage heart failure. Int. J. Cardiol. 2012, 159, 225-229. [CrossRef]

42. Papp, Z.; Agostini, P.J.; Alvarez, J.; Bettex, D.; Bouchez, S.; Brito, D.; Cerny, V.; Comin-Colet, J.; Crespo-Leiro, M.G.; Delgado, J.F.; et al. Levosimendan efficacy and safety: 20 years of SIMDAX in clinical use. Cardiovasc. Pharmacol. 2020, 76, 4-22. [CrossRef]

43. Lund, L.H.; Edwards, L.B.; Dipchand, A.I.; Goldfarb, S.; Kucheryavaya, A.Y.; Levvey, B.J.; Lund, L.H.; Meiser, B.; Rossano, J.W.; Yusen, R.D.; et al. The registry of the international society of heart and lung transplantation: Thir-ty-third adult heart transplantation report-2016; focus theme: Primary diagnostic indications for transplant. J. Heart. Lung Transpl. 2016, 35, 1158-1169. [CrossRef]

44. Swisstransplant annual report, 2020, page 66. Available online: www.swisstransplant.org (accessed on 30 January 2022).

45. Estep, J.D.; Starling, R.C.; Horstmanshof, D.A.; Milano, C.A.; Selzman, C.H.; Shah, K.B.; Loebe, M.; Moazami, N.; Long, J.W.; Stehlik, J.; et al. Risk assessment and comparative effectiveness of left ventric-ular assist device and medical management in ambulatory heart failure patients: Results from the ROADMAP study. J. Am. Coll. Cardiol. 2015, 66, 1747-1761. [CrossRef]

46. Miller, L.; Birks, E.; Guglin, M.; Lamba, H.; Frazier, O. Use of Ventricular Assist Devices and Heart Transplantation for Advanced Heart Failure. Circ. Res. 2019, 124, 1658-1678. [CrossRef] [PubMed]

47. Bowen, R.E.S.; Graetz, T.J.; Emmert, D.A.; Avidan, M.S. Statistics of heart failure and mechanical circulatory support in 2020. Ann. Transl. Med. 2020, 8, 827. [CrossRef] [PubMed]

48. Ambardekar, A.V.; Forde-McLean, R.C.; Kittleson, M.M.; Stewart, G.C.; Palardy, M.; Thibodeau, J.; DeVore, A.; Mountis, M.M.; Cadaret, L.; Teuteberg, J.J.; et al. High early event rates in patients with questionable eligibility for advanced heart failure therapies: Results from the Medical Arm of Mechanically Assisted Circulatory Support (Medamacs) Registry. J. Heart Lung Transpl. 2016, 35, 722-730. [CrossRef] [PubMed]

49. Cowger, J.; Shah, P.; Stulak, J.; Maltais, S.; Aaronson, K.D.; Kirklin, J.K.; Pagani, F.; Salerno, C. INTERMACS profiles and modifiers: Heterogeneity of patient classification and the impact of modifiers on predicting patient outcome. J. Heart Lung Transpl. 2015, 35, 440-448. [CrossRef] [PubMed]

50. Gustafson, F.; Rogers, J.G. Left ventricular assist device therapy in advanced heart failure: Patient selection and outcomes. Eur. J. Heart Fail. 2019, 19, 595-602. [CrossRef]

51. Stevenson, L.W.; Pagani, F.; Young, J.B.; Jessup, M.; Miller, L.; Kormos, R.L.; Naftel, D.C.; Ulisney, K.; Desvigne-Nickens, P.; Kirklin, J.K. INTERMACS Profiles of Advanced Heart Failure: The Current Picture. J. Heart Lung Transpl. 2009, $28,535-541$. [CrossRef] [PubMed]

52. Kormos, R.L.; Cowger, J.; Pagani, F.D.; Teuteberg, J.J.; Goldstein, D.J.; Jacobs, J.P.; Higgins, R.S.; Stevenson, L.W.; Stehlik, J.; Atluri, P.; et al. The Society of Thoracic Surgeons Intermacs database annual report: Evolving in-dications, outcomes, and scientific partnerships. Ann. Thorac. Surg. 2019, 107, 341-353. [CrossRef]

53. Mehra, M.R.; Naka, Y.; Uriel, N.; Goldstein, D.J.; Cleveland, J.C.; Yuzefplskaya, M.; Salerno, C.; Walsh, M.N.; Milano, C.A.; Patel, C.B.; et al. A Fully Magnetically Levitated Circulatory Pump for Advanced Heart Failure. N. Engl. J. Med. 2017, 376, 440-450. [CrossRef] 
54. Nowacka, A.; Hullin, R.; Tozzi, P.; Barras, N.; Regamey, J.; Yerly, P.; Rosner, L.; Marcucci, C.; Rusca, M.; Liaudet, L.; et al. Short-term single-center experience with the HeartMate 3 left ventricular assist de-vice for advanced heart failure. Eur. J. Cardiothorac. Surg. 2020, 58, 511-518. [CrossRef]

55. Schaeffer, T.; Pfister, O.; Mork, C.; Mohacsi, P.; Rueter, F.; Scheifele, S.; Morgen, A.; Zenklusen, U.; Doebele, T.; Maurer, M.; et al. 5-year results of a newly implemented mechanical circulatory support program for terminal heart failure patients in a Swiss non-cardiac transplant university hospital. J. Cardiothorac. Surg. 2021, 16, 1-10. [CrossRef] [PubMed]

56. Kirklin, J.K.; Pagani, F.; Kormos, R.L.; Stevenson, L.W.; Blume, E.D.; Myers, S.L.; Miller, M.A.; Baldwin, J.T.; Young, J.B.; Naftel, D.C. Eighth annual INTERMACS report: Special focus on framing the impact of adverse events. J. Heart Lung Transpl. 2017, 36, 1080-1086. [CrossRef] [PubMed]

57. Adamson, R.M.; Stahovich, M.; Chillcott, S.; Baradarian, S.; Chammas, J.; Jaski, B.; Hoagland, P.; Dembitsky, W. Clinical Strategies and Outcomes in Advanced Heart Failure Patients Older Than 70 Years of Age Receiving the HeartMate II Left Ventricular Assist Device: A Community Hospital Experience. J. Am. Coll. Cardiol. 2011, 57, 2487-2495. [CrossRef] [PubMed]

58. Mohamedali, B.; Yost, G.; Bhat, G. Obesity as a Risk Factor for Consideration for Left Ventricular Assist Devices. J. Card. Fail. 2015, 21, 800-805. [CrossRef] [PubMed]

59. Aittigrine, S.; Tozzi, P.; Hullin, R.; Yerly, P.; Regamey, J.; Rösner, L.; Rusca, M.; Kirsch, M.; Suter, M.; Mantziari, S. Laparoscopic sleeve gastrectomy for class III obesity in a patient with a left ventricular assist device (LVAD) Heartmate III. Surg. Obes. Relat. Dis. 2019, 15, 1420-1421. [CrossRef]

60. Maurer, M.S.; Horn, E.; Reyentovich, A.; Dickson, V.V.; Pinney, S.; Goldwater, D.; Goldstein, N.E.; Jiminez, O.; Teruya, S.; Goldsmith, S.; et al. Can a left ventricular assist device in individuals with advanced systolic heart failure improve or reverse frailty? J. Am. Geriatr. Soc. 2017, 65, 2383-2390. [CrossRef] [PubMed]

61. Kirklin, J.K.; Naftel, D.C.; Kormos, R.L.; Pagani, F.; Myers, S.L.; Stevenson, L.W.; Givertz, M.M.; Young, J.B. Quantifying the effect of cardiorenal syndrome on mortality after left ventricular assist device implant. J. Heart Lung Transpl. 2013, 32, 1205-1213. [CrossRef]

62. Hasin, T.; Topilsky, Y.; Schirger, J.A.; Li, Z.; Zhao, Y.; Boilson, B.A.; Clavell, A.L.; Rodeheffer, R.J.; Frantz, R.P.; Edwards, B.S.; et al Changes in Renal Function After Implantation of Continuous-Flow Left Ventricular Assist Devices. J. Am. Coll. Cardiol. 2012, 59, 26-36. [CrossRef]

63. Uriel, N.; Naka, Y.; Colombo, P.C.; Farr, M.; Pak, S.W.; Cotarlan, V.; Albu, J.B.; Gallagher, D.; Mancini, D.; Ginsberg, H.N.; et al. Improved diabetic control in advanced heart failure patients treated with left ventric-ular assist devices. Eur. J. Heart. Fail. 2011, 13, 195-199. [CrossRef]

64. Bansal, A.; Uriel, N.; Colombo, P.C.; Narisetty, K.; Long, J.E.; Bhimaraj, A.; Cleveland, J.C.; Goldstein, D.J.; Stulak, J.M.; Najjar, S.S.; et al. Effects of a fully magnetically levitated centrifugal -flow versus axial-flow left ven-tricular assist device on the von Willebrand factor: A prospective multicenter trial. J. Heart Lung Transpl. 2019, 38, 806-816. [CrossRef]

65. Calson, L.A.; Maynes, E.J.; Choi, J.H.; Hallett, A.M.; Horan, D.P.; Weber, M.P.; Deb, A.K.; Patel, S.; Samuels, L.E.; Morris, J.R.; et al. Characteristics and outcomes of gastrointestinal bleeding in patients with continu-ous-flow left ventricular assist devices: A systematic review. Artific. Organs 2020, 44, 1150-1161. [CrossRef]

66. Hullin, R.; Regamey, J.; Yerly, P.; Aur, S.; Abdurashidova, T.; Rancati, V.; Tozzi, P.; Kirsch, M. Advanced heart failure: When and what to consider for left ventricular assist device implantation. Cardiovasc. Med. 2021, 24, w10079.

67. Saeed, D.; Muslem, R.; Rasheed, M.; Caliskan, K.; Kalampoka, N.; Sipahi, F.; Lichtenberg, A.; Jawad, K.; Borger, M.; Huhn, S.; et al. Less invasive surgical implant strategy and right heart failure after LVAD implanta-tion. J. Heart Lung Transpl. 2021, 40, 289-297. [CrossRef] [PubMed]

68. Chang, S.-A.; Kim, H.-K.; Kim, Y.-J.; Cho, G.-Y.; Oh, S.; Sohn, D.-W. Role of pericardium in the maintenance of left ventricular twist. Heart 2010, 96, 785-790. [CrossRef] [PubMed]

69. Khalpey, Z.; Bin Riaz, I.; Marsh, K.M.; Ansari, M.Z.A.; Bilal, J.; Cooper, A.; Paidy, S.; Schmitto, J.D.; Smith, R.; Friedman, M.; et al Robotic Left Ventricular Assist Device Implantation Using Left Thoracotomy Approach in Patients with Previous Sternotomies. ASAIO J. 2015, 61, e44-e46. [CrossRef] [PubMed]

70. Khalpey, Z.; Sydow, N.; Slepian, M.J.; Poston, R. How to do it: Thoracoscopic left ventricular assist device implantation using robot assistance. J. Thorac. Cardiovasc. Surg. 2013, 147, 1423-1425. [CrossRef] [PubMed]

71. Kapur, N.K.; Esposito, M.L.; Bader, Y.; Morine, K.J.; Kiernan, M.S.; Pham, D.T.; Burkhoff, D. Mechanical Circulatory Support Devices for Acute Right Ventricular Failure. Circulation 2017, 136, 314-326. [CrossRef]

72. Farag, J.; Woldendorp, K.; McNamara, N.; Bannon, P.G.; Marasco, S.F.; Loforte, A.; Potapov, E.V. Contemporary outcomes of continuous-flow biventricular assist devices. Ann. Cardiothorac. Surg. 2021, 10, 311-328. [CrossRef]

73. Noly, P.E.; Ali, B.E.; Lamarche, Y.; Carrier, M. Carrier, Status, Indications, and Use of Cardiac Replacement Therapy in the Era of Mul-timodal Mechanical Approaches to Circulatory Support: A Scoping Review. Can. J. Cardiol. 2020, 36, 261-269. [CrossRef]

74. Hullin, R. Heart transplantation: Current practice and outlook to the future. Swiss Med. Wkly. 2014, 144. [CrossRef]

75. Colvin, M.; Smith, J.M.; Hadley, N.; Uccellini, K.; Goff, R.; Foutz, J.; Israni, K.; Snyder, J.J.; Kasiske, B.L. OPTN/SRTR 2018 Annual Data Report: Heart. Am. J. Transpl. 2020, 20, 340-426. [CrossRef]

76. Zurbuchen, A.; Tozzi, P.; Regamey, J.; Abdurashidova, T.; Meyer, P.; Lefol, K.; Pascual, M.; Yerly, P.; Aubert, V.; Aur, S.; et al Has the Profile of Heart Transplantation Recipients changed within the last 3 decades? An analysis from the Lausanne Heart Transplantation Center. Swiss Med. Wkly. 2022, 152, w30108. 
77. Stern, L.K.; Velleca, A.; Nishihara, K.; Shen, A.; Zaliznyak, M.; Patel, J.; Hamilton, M.A.; Ramzy, D.; Esmalian, F.; Kobashigawa, J.A.; et al. Impact of the United Network for organ sharing 2018 donor heart allocation sys-tem on transplant morbidity and mortality. Clin. Transpl. 2021, 35, e14181. [CrossRef] [PubMed]

78. Jawitz, O.K.; Fudim, M.; Raman, V.; Bryner, B.S. Reassessing Recipient Mortality Under the New Heart Allocation System: An Up-dated UNOS Registry Analysis. JACC Heart Fail. 2020, 8, 548-556. [CrossRef] [PubMed]

79. Menachem, J.N.; Schlendorf, K.H.; Mazurek, J.A.; Bichell, D.P.; Brinkley, D.; Frischhertz, B.P.; Mettler, B.A.; Shah, A.S.; Zalawadiya, S.; Book, W.; et al. Advanced Heart Failure in Adults with Congenital Heart Disease. JACC Heart Fail. 2019, 8, 87-99. [CrossRef] [PubMed]

80. Lund, L.H.; Edwards, L.B.; Kucheryavaya, A.Y.; Benden, C.; Dipchand, A.I.; Goldfarb, S.; Levvey, B.J.; Meider, B.; Rossano, J.W.; Yusen, R.D.; et al. The registry of the International Society of Heart and Lung Transplantation: Thirty-second official adult heart transplantation report: 2015; Theme: Early graft failure. J. Heart Lung Transpl. 2015, 34, 1244-1254. [CrossRef] [PubMed]

81. Cedars, A.; Vanderpluym, C.; Koehl, D.; Cantor, R.; Kutty, S.; Kirklin, J.K. An Interagency Registry for mechanically assisted circulatory support (INTER-MACS) analysis of hospitalization, functional status, and mortality after mechanical circulatory support in adults with congenital heart disease. J. Heart Lung Transpl. 2018, 37, 619-630. [CrossRef] [PubMed]

82. Monda, E.; Lioncino, M.; Pacileo, R.; Rubino, M.; Cirillo, A.; Fusco, A.; Esposito, A.; Verrillo, F.; Di Fraia, F.; Mauriello, A.; et al. Advanced Heart Failure in Special Population-Pediatric Age. Heart Fail. Clin. 2021, 17, 673-683. [CrossRef]

83. Khush, K.K.; Zaroff, J.G.; Nguyen, J.; Menza, R.; Goldstein, B.A. National decline in donor heart utilization with regional variabil-ity: 1995-2010. Am. J. Transpl. 2015, 15, 642-649. [CrossRef]

84. Costanzo, M.R.; Dipchand, A.; Starling, R.; Anderson, A.; Chan, M.; Desai, S.; Fedson, S.; Fisher, P.; Gonzales-Stawinski, G.; Martinelli, L.; et al. The International Society of Heart and Lung Transplantation Guidelines for the care of heart transplant recipients. J. Heart Lung Transpl. 2010, 29, 914-956. [CrossRef]

85. Kransdorf, E.P.; Kittleson, M.M.; Benck, L.R.; Patel, J.K.; Chung, J.S.; Esmailian, F.; Kearney, B.L.; Chang, D.H.; Ramzy, D.; Czer, L.S.C.; et al. Predicted heart mass is the optimal metric for size match in heart trans-plantation. J. Heart Lung Transpl. 2019, 38, 156-165. [CrossRef]

86. Holzhauser, L.; Imamura, T.; Bassi, N.; Fujino, T.; Nitta, D.; Kanelidis, A.J.; Narang, N.; Kim, G.; Raikhelkar, J.; Murks, C.; et al. Increasing heart transplant donor pool by liberalization of size matching. J. Heart Lung Transpl. 2019, 38, 1197-1205. [CrossRef] [PubMed]

87. Jain, R.; Habal, M.V.; Clerkin, K.J.; Latif, F.; Restaino, S.W.; Zorn, E.; Takeda, K.; Naka, Y.; Yuzefpolskaya, M.; Farr, M.A.; et al. De novo human leukocyte antigen allosensitization in Heartmate 3 versus Heartmate II left ventricular assist device recipients. ASAIO J. 2022. [CrossRef] [PubMed]

88. Al-Mohaissen, M.A.; Virani, S.A. Allosensitization in Heart Transplantation: An Overview. Can. J. Cardiol. 2014, 30, 161-172. [CrossRef]

89. Chaidaroglou, A.; Armenis, I.; Gkouziouta, A.; Bonios, M.J.; Kogerakis, N.; Fragoulis, S.; Leontiadis, E.; Zarkalis, D.; Stavridis, G.; Kaklamis, L.; et al. The effect of paracorporeal pulsatile biventricular assist devices on allo-sensitization in adults: A comparison with left ventricular assist devices. Transplant. Immunol. 2021, 69, 101477. [CrossRef] [PubMed]

90. Nwakanma, L.U.; Williams, J.A.; Weiss, E.S.; Russell, S.D.; Baumgartner, W.A.; Conte, J.V. Influence of Pretransplant PanelReactive Antibody on Outcomes in 8,160 Heart Transplant Recipients in Recent Era. Ann. Thorac. Surg. 2007, 84, 1556-1563. [CrossRef]

91. Kransdorf, E.P.; Kittleson, M.M.; Patel, J.K.; Pando, M.J.; Steidley, D.E.; Kobashigawa, J.A. Calculated panel- reactive antibody predicts outcomes on the heart trans-plant waiting list. J. Heart Lung Transpl. 2017, 36, 787-796. [CrossRef]

92. Timofeeva, O.A.; Alvarez, R.; Pelberg, J.; Yoon, E.; Alsammak, M.; Geier, S.S.; Ruggia-Check, C.; Hassler, J.; Hoosain, J.; Brisco, M.A.; et al. Serum dilutions as a predictive biomarker for peri-operative desensitization: An exploratory approach to transplanting sensitized heart candidates. Transpl. Immunol. 2020, 60, 101274. [CrossRef]

93. Chih, S.; Patel, J. Desensitization strategies in adult heart transplantation-will persistence pay off? J. Heart Lung Transpl. 2016, 35, 962-972. [CrossRef]

94. Kobashigawa, J.; Colvin, M.; Potena, L.; Dragun, D.; Crespo-Leiro, M.G.; Delgado, J.F.; Olymbios, M.; Parameshwar, J.; Patel, J.; Reed, E.; et al. The management of antibodies in heart transplantation: An ISHLT consensus document. J. Heart Lung Transpl. 2018, 37, 537-547. [CrossRef]

95. Al Saadi, T.; Lawrecki, T.; Narang, L.; Joshi, A.; Sciamanna, C.; Pauwaa, S.; Macaluso, G.; Tatooles, A.; Pappas, P.; Cotts, W.; et al. Outcomes of pre- heart transplantation desensitization in a series of highly sensi-tized patients bridged with left ventricular assist devices. J. Heart Lung Transpl. 2021, 40, 1107-1111. [CrossRef] [PubMed]

96. Starling, R.C.; Armstrong, B.; Bridges, N.D.; Eisen, H.; Givertz, M.M.; Kfoury, A.G.; Kobashigawa, J.; Ikle, D.; Morrison, J.; Pinney, S.; et al. Accelerated Allograft Vasculopathy With Rituximab After Cardiac Transplan-tation. J. Am. Coll. Cardiol. 2019, 74, 36-51. [CrossRef] [PubMed]

97. Yerly, P.; Rotman, S.; Regamey, J.; Aubert, V.; Aur, S.; Kirsch, M.; Hullin, R.; Pascual, M. Complement blockade with eculizumab to treat acute symptomatic humoral rejec-tion after heart transplantation. Xenotransplantation 2022, 10, e12726.

98. Bretschneider, H.J.; Hübner, G.; Knoll, D.; Lohr, B.; Nordbeck, H.; Spieckermann, P.G. Myocardial resistance and tolerance to ischemia: Physiological and biochem-ical basis. J. Cardiovasc. Surg. 1975, 16, 241-620. 
99. Copeland, H.; Hayanga, J.A.; Neyrinck, A.; MacDonald, P.; Dellgren, G.; Bertolotti, A.; Khuu, T.; Burrows, F.; Copeland, J.G.; Gooch, D.; et al. Donor heart and lung procurement: A consensus statement. J. Heart Lung Transpl. 2020, 39, 501-517. [CrossRef]

100. Naito, N.; Funamoto, M.; Pierson, R.N.; D'Alessandro, D.A. First clinical use of a novel hypothermic storage system for a long-distance donor heart procurement. J. Thorac. Cardiovasc. Surg. 2019, 159, e121-e123. [CrossRef]

101. Guenthart, B.A.; Krishnan, A.; Koyano, T.; La Francessca, S.; Chan, J.; Alassar, A.; Macarthur, J.W.; Shudo, Y.; Hiesinger, W.; Woo, Y.J. Extended Static Hypothermic Preservation In Cardiac Transplantation: A Case Report. Transpl. Proc. 2021, 53, $2509-2511$. [CrossRef]

102. Lund, L.H.; Khush, K.K.; Cherikh, W.S.; Goldfarb, S.; Kucheryavaya, A.Y.; Levvey, B.J.; Meiser, B.; Rossano, J.W.; Chambers, D.W.; Yusen, R.D.; et al. The Registry of the International Society for Heart and Lung Transplantation: Twen-tieth Adult Heart Transplantation Report-2017; Focus Theme: Allograft ischemic time. J. Heart Lung Transpl. 2017, 36, 1037-1046. [CrossRef]

103. Ardehali, A.; Esmailian, F.; Deng, M.; Soltesz, E.; Hsich, E.; Naka, Y.; Mancini, D.; Camacho, M.; Zucker, M.; Leprince, P.; et al. Ex-vivo perfusion of donor hearts for human heart transplantation (PROCEED II): A prospective, open-label, multicentre, randomised non-inferiority trial. Lancet 2015, 385, 2577-2584. [CrossRef]

104. Schroder, J.N. Successful Utilization of Extended Criteria Donor (ECD) Hearts for Transplanation- Results of the OCS Heart Expand Trial to Evaluate the Effectiveness and Safety of the OCS Heart System to Preserve and Assess ECD Hearts for Transplantation. J. Heart Lung Transpl. 2019, 38, S42. [CrossRef]

105. Sponga, S.; Bonetti, A.; Ferrara, V.; Beltrami, A.P.; Isola, M.; Vendramin, I.; Finato, N.; Ortolani, F.; Livi, U. Preservation by cold storage vs ex vivo normothermic perfusion of marginal donor hearts: Clinical, histopathologic, and ultrastructural features. $J$. Heart Lung Transpl. 2020, 39, 1408-1416. [CrossRef] [PubMed]

106. Jain, P.; Prichard, R.A.; Connellan, M.B.; Dhital, K.K.; Macdonald, P.S. Long distance heart transplantation: A tale of two cities. Intern. Med. J. 2017, 47, 1202-1205. [CrossRef] [PubMed]

107. Stamp, N.L.; Shah, A.; Vincent, V.; Wright, B.; Wood, C.; Pavey, W.; Cokis, C.; Chih, S.; Dembo, L.; Larbalestier, R. Successful Heart Transplant after Ten Hours Out-of-body Time using the TransMedics Organ Care System. Heart Lung Circ. 2015, 24, 611-613. [CrossRef] [PubMed]

108. Mehra, M.R.; Canter, C.E.; Hannan, M.M.; Semigran, M.J.; Uber, P.A.; Baran, D.A.; Danziger-Isakov, L.; Kirklin, J.K.; Kirk, R.; Kushwaha, S.S.; et al. The 2016 International Society for Heart Lung Transplantation listing criteria for heart transplantation: A 10-year update. J. Heart Lung Transpl. 2016, 35, 1-23. [CrossRef]

109. Piperata, A.; Caraffa, R.; Bifulco, O.; Avesani, M.; Gerosa, G.; Bottio, T. Heart transplantation in the new era of extended donor criteria. J. Card. Surg. 2021, 36, 4828-4829. [CrossRef]

110. Weiss, J.; Beyeler, F.; Immer, F.F. Heart Swisstransplant Heart Working Group (STAH) Heart allocation and transplantation in Switzerland since the introduction of the Swiss Organ Allocation System (SOAS). Swiss Med. Wkly. 2014, 144, w14057. [CrossRef]

111. Cowger, J.; Sundareswaran, K.; Rogers, J.G.; Park, S.J.; Pagani, F.D.; Bhan, G.; Jask, B.; Farrar, D.J.; Slaughter, M.S. Predicting survival in patients receiving continuous flow left ventricular assist devices: The HeartMate II risk score. J. Am. Coll. Cardiol. 2013, 61, 313-321. [CrossRef] 